\title{
SYMBOLIC MEANINGS OF KEMBAR MAYANG IN
}

JAVANESE WEDDING CEREMONY AT DESA MEDAN

SINEMBAH KECAMATAN TANJUNG MORAWA KABUPATEN DELI SERDANG

\author{
Indra Purnawan Panjaitan and M. Manugeren \\ Magister Sastra Inggris, Fakultas Sastra, Universitas Islam Sumatera Utara, Medan, \\ Indonesia \\ email: fatih_ist92@yahoo.co.id
}

Received: 25 Maret 2019

Accepted: 19 July 2019

\begin{abstract}
This study is aimed at analyzing the symbolic meanings of Kembar Mayang conducted at Desa Medan Sinembah Kecamatan Tanjung Morawa Kabupaten Deli Serdang predominantly by Javanese ethnic. Kembar Mayang in this study is concerned with the Javanese wedding ceremony. Descriptive qualitative method is applied in the study describing social phenomena occurring naturally aiming to help us to understand the world in which we live and why things are in the way they are. The main theory to support the study is the theory of Semiotic. The results show there are five forms of symbolic meanings in Kembar Mayang: Manuk-Manukan as symbol of Loyalty; Uler-Uleran of Struggle; Walang-Walangan of Persistence; Pecut-Pecutan of Optimism and Keris-Kerisan of Wisdom. The five forms of rites are compulsory in the wedding ceremony with the main objective to achieve a happy, harmonious and peaceful life for the bride and the bridegroom and this is in line with the general concept of marriage.
\end{abstract}

Keywords: loyalty, struggle, persistence, optimism, wisdom

\section{Introduction}

Jawa ethnic, as one of the largest ethnic groups in Indonesia has diverse cultures. Some people assume that what is meant by Jawa ethnic are people born in and inhabiting the area of West Java, Central Java and East Java and speaking Javanese language. However, in reality in addition to those three provinces, many Javanese people are found in other regions of Indonesia, including Medan, the capital of the province of North Sumatra. (Suryadinata in Hidayati: 2018)

The study is Symbolic Meanings of Kembar Mayang in Javanese Wedding at Desa Medan Sinembah, Kecamatan Tanjung Morawa, Kabupaten Deli Serdang. There are five symbolic meanings to be analyzed under this title: symbols of loyalty, struggle, persistence, optimism and wisdom.

Kembar Mayang is an object which has symbols and meanings. Every symbol has sound advice for the bridegroom and the bride. Kembar Mayang is originally made exclusively for a royal wedding but later it becomes mandatory for Javanese wedding of all classes. Kembar Mayang serves as a message to newlyweds, that they shall be able to 
maintain their marriage despite obstacles and challenges. It is related to the process of 'making Kembar Mayang wherein the maker must be sincere and use only the best materials. While making it, one must allocate time and avoid procrastination. It stipulates that marriage is a once in a lifetime event and that the making of Kembar Mayang must be done in the best place available. It also signifies that marriage is performed with a loving heart. Prayer typically precedes and follows the making of Kembar Mayang.

Kembar Mayang, besides being a decoration has a lot of meanings. Kembar Mayang is a guidance or advice in wading new life. "Kembar Mayang is sekar manca warna paring ing dewa or various kinds of flowers as the gifts from God, and cannot be bought with money, but should be gained with determination and courage; bekti ing men or devoted to the husband, manut miturut or obedient to the parents "(Suwardi, 1993: 111). "Kembar Mayang is the arrangement of flowers that has meaning to eliminate all dangers, so the bride and groom will get easiness in running the marriage life. (Widagda, 2003: 14).

Kembar Mayang or in other words known as bouquet is a series ornaments made of janur (coconut leaves), Mayang (areca flowers), and some types of foliage (various kinds of leaves) which all are plugged in pieces of banana stems. Kembar Mayang has a form like hayat tree symbolizing the tree of life which gives everything desirable.

Janur derives from ja'a means come, nur means light. And kuning derives from Javanese term wening (sing wening) means Almighty. Wong urip iku tansah eling marang Seng Wening (human beings always have to remember God, the Almighty. So human beings have to know who creates them and to whom they will come back.

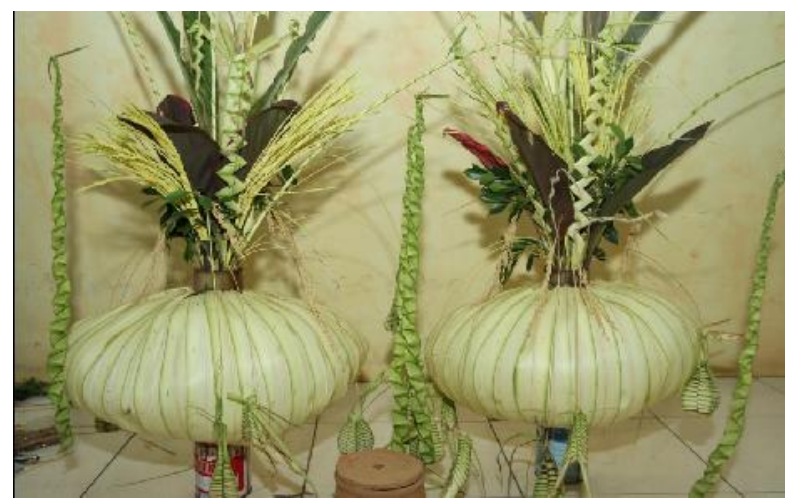

Figure 1. Kembar Mayang

In Javanese wedding, Panggih ceremony is a representative of Javanese philosophy of married life. One of the symbols included in Panggih ceremony is Kembar Mayang. Kembar Mayang derives from the words Kembar and Mayang. Kembar means equal (podho) and Mayang is heart (ati). So Kembar Mayang means to unite two different having the same goal.

Many kinds of colours are there in Kembar Mayang describing that human beings cannot live without colours as colours are the atmosphere of life. According to Suwardi (1993: 57) all forms of Kembar Mayang, can be viewed as follows:

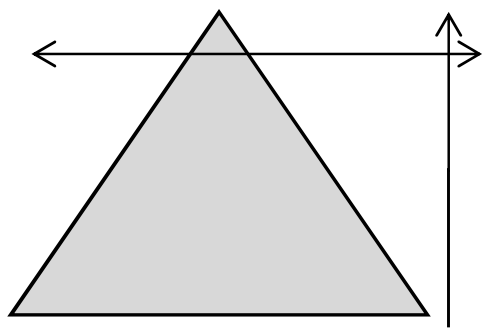


Vertical line shows that human beings always look for the Almighty to worship, and ask for lawful sustenance. Horizontal line indicates the relationships among people in society, as shown by symbolic meanings in Kembar Mayang.

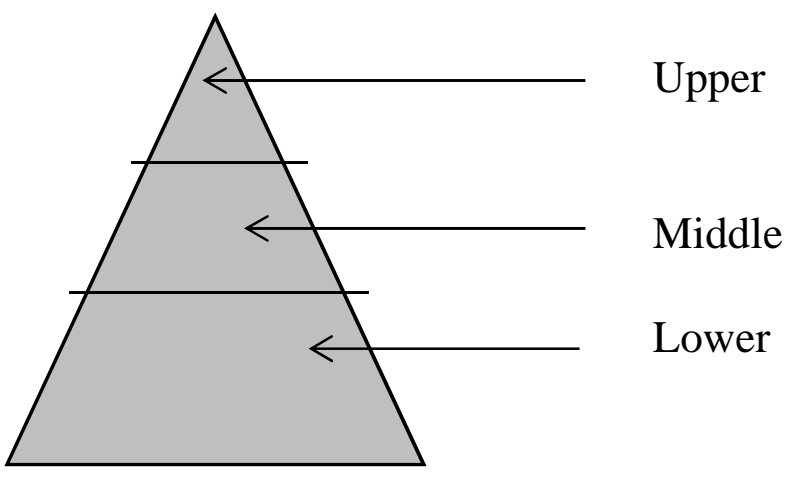

The upper part, shows that man must be careful, thrifty, trustworthy, and he must always pray to God, the Almighty. The middle part, the colour of life in society, is the full of variations, which must be faced, and achieved with high motivation. The bottom, is the foundation of life, always growing, being sturdy, and resistant from the shock of life.

\section{Literature Review}

\subsection{Semiotics}

As the study is concerned with meanings, then semiotics becomes the base of interpreting the objects of research. Semiotics is the study of the properties of signaling systems, whether natural or artificial. It refers to the study within philosophy of sign and symbol systems in general. Pierce (1990: 78) sees the field as divisible into three areas: the relationship between linguistic expression and the objects in the world which they refer to or describe, the relation of these expressions to each other and the dependence's meaning of these expression on their uses.

This study has a reference to Piercean theory of sign. The peircean sign has been defined as something that is related to something else for someone in some respect or capacity. (Cobley, 2000: 28). In addition to this, Thornbury (2011) states that conventional sign, based on an arbitrary association with its object and governed by a rule for its use, is just one of three categories of sign.

Peirce develops triad concept of sign as seen below.

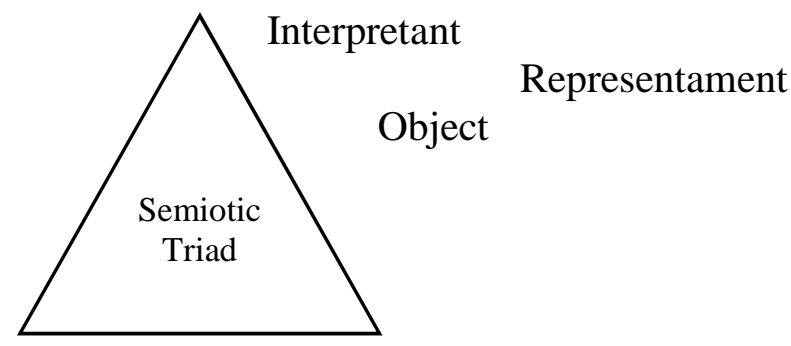

Figure 5. Concept of sign

The above concept of sign is called triadic. 
1. Triadic concept of sign: Representament (the thing that represents), Object (concept that is represented), Interpretant (what the sign means for someone).

2. Three modes of representation: Iconic (by miming, simulating), Indexical (by pointing, indicating), Symbolic (by convention)

The theory of sign can be analogized below:

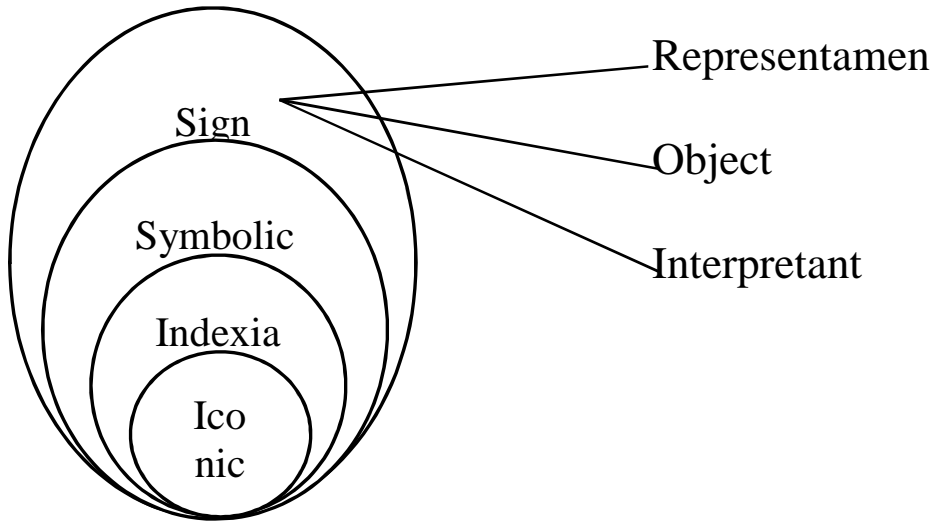

Figure 3. The analogy of Peirce's theory

I define a sign as anything which is so determined by something else, called its Object, and so determines an effect upon a person, which effect I call its interpretant, that the later is thereby immediately determined by the former. (Peirce, 1990: 43)

\section{Research Method}

This study is conducted by means of descriptive qualitative research to find out the symbolic meanings of "KembarMayang" in Javanese traditional wedding ceremony. Qualitative research is concerned with the opinions, experiences and feeling of individuals producing subjective data. It describes social phenomena as they occur naturally. No attempt is made to manipulate the situation under the study as is the case with experimental qualitative research. (Hancock, 1998: 98)

\section{Discussion}

A wedding is a ceremony where two people are united in marriage. Wedding tradition and customs vary greatly between cultures, ethnic groups, religions, countries, and social classes. Most wedding ceremonies involve an exchange of wedding vows wedding vows by the couple, presentation of a gift (offering, ring(s), symbolic item, flowers, money), and a public proclamation of marriage by an authority figure or leader. Special wedding garments are often worn, and the ceremony is sometimes followed by a wedding reception.

Jawa ethnic strongly adheres to tradition or customs that they have and always carry them out well. For Javanese people, if there are some Javanese people who do not do the Javanese traditions or customs, they will be considered weird and often get reproached from the surrounding communities. The term for the Javanese is more identical for the people who adhere to the philosophy of customs. (Hidayati: 2018) Music, poetry, prayers or readings from religious texts or literature are also commonly 
incorporated into the ceremony and following this, symbolic meanings of loyalty, struggle, persistence, optimism and wisdom are commonly found in Javanese wedding.

\subsection{Manuk-manukan as symbol of loyalty}

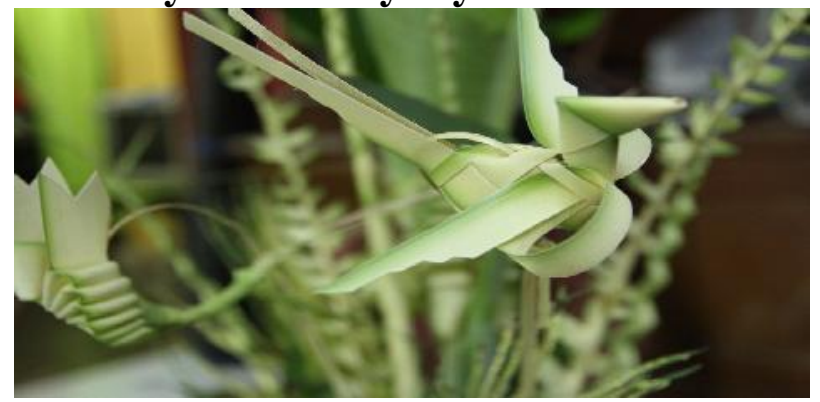

Figure 4. Manuk-manukan

According to Ruth (2011: 34) loyalty is based on the principles of truth and conscience. Loyalty is not hypocritical. Loyalty is also based on a proper understanding about what should be done to realize the truth when faced with a hesitation. Related to family life, loyalty is the main foundation to make a harmonious family. No suspicion of what has been done and trust each other.

The first symbol in Kembar Mayang is Manuk-manukan. As a human being, the lesson can be learned from the character of the bird. The character of the bird is loyal to its mate, especially pigeon. Pigeon is an animal which has a number of uniqueness, one that stands out is the loyalty to the couple, a pair of pigeon promise to be faithful until death. Usually a male pigeon will not change partners with another female pigeon. The character of pigeon is a symbol of loyalty. By learning the character of a pigeon, a person is expected to instill loyalty in his life, especially in carrying out married life. As known that loyalty in the marriage is important as a basic line to carry out the household. It is said like that because loyalty is a mandate and responsibility from married couples to the permanence of marriage. The prayer in Manuk-manukan is as follows:

Manuk kutut meniko alit tapi manggunge angeng dados sri penganten

kaleh meniko saiki sampon berumah tangga sageto biso lulut rukun rumah tanggae pun sri pengangen anyar kaleh menik. (Koentjaraningrat: 1984: 90)

There is a mention of zebra-dove, a bird, in the above lines. The zebra-dove belongs to the family of pigeon and this pigeon has already been known for its loyalty to the mate. So it is expected that the newly-married couple should also be loyal to each other and loyalty is surely to become a shield in marriage preservation. Next to this they are also expected to lead a harmonious married life as disharmony is a trigger to any conflict. When loyalty combined with harmony is present in the midst of the newlymarried couple, there will be no impediment anymore for them.

So loyalty is the main foundation to make a harmonious family.

\subsection{Uler-Uleran as a symbol of struggle}




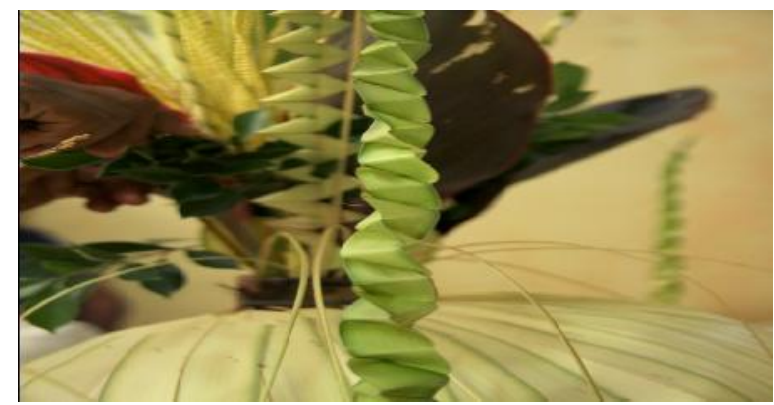

Figure 5. Uler-uleran

In the world, it is not possible for someone who experiences a success without starting with struggle. In the struggle, there are various obstacles. So the more various problems that someone gets, the more powerful his character will be. Life cannot be separated from struggle. It is not easy to build a household. A lot of marriages fail because the couple do not have any spirit of struggle. They have to fight hard against all the obstacles and if they pass, then they will be given a reward in the form of harmonious marriage life. (John, 2010: 87)

sri penganten kaleh meniko sakniki sampon berumah tangga sageto

pados sandang pangan nggremet slamet kados uleran

(Koentjaraningrat: 1984: 89)

The couple should learn from the caterpillar's life. It is hatched from a very small egg stuck on the leaves or branches. Then as time goes by, the caterpillar starts to look for food. After its body becomes big and grown, it begins to eat much for the preparation process of metamorphosis, and when it is considered quite enough for its stomach, then the process of metamorphosis begins. At first the caterpillar will approach a branch of the tree, then the caterpillar ejects mucus threads from its mouth to form a pupa / cocoon.

Caterpillar seems to have no time at all. The time available for the caterpillar is valuable to fatten its body as a preparation to pass a process and it needs big energy to become a cocoon and the caterpillar never rests to eat the leaves of plant. The caterpillar, motivated by the running time, has a clear goal to achieve a cocoon period. After a while finally the caterpillar turns into a beautiful butterfly. Extraordinary struggle is experienced the new butterfly. It has to struggle again to come out of the cocoon. The wings are still wet and it cannot fly. It has to be patient waiting till all the wings get dry and then the flying will start. All needs time, patience and struggle.

A message that can be taken from the caterpillar is a struggle to become a butterfly and it is not easy. It also takes time to become a beautiful butterfly. The same thing will happen to a newly-married couple. They have to work hard and at the same time they have to maintain patience. When all the difficulties could be faced with a high spirit, only then the couple will taste a happy and harmonious life.

\subsection{Walang walangan as a symbol of Persistence}




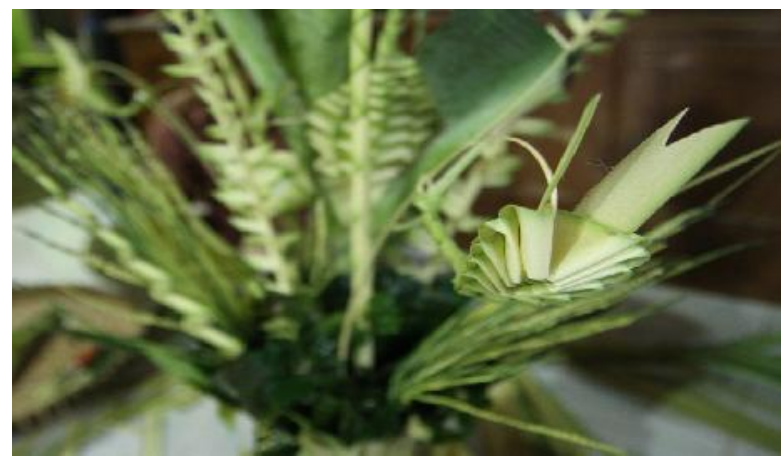

Figure 5. Walang-walangan

Persistence is the ability, capability, and self-compulsion to do the work or action continuously, regardless of any situation. Persistence is one of the factors to make someone successful. When we have goals and strive hard to achieve it, all will be running well. Persistence is a skill that can help a person achieve the goal, and to get what is wanted. Actually, lack of persistence or "too quick to give up" is the most common cause of failure in the attempt. (Lawrence, 2009: 142)

This the third symbol in Kembar Mayang, Walang walangan. Symbol of Walangwalangan means the husband and wife should be enthusiastic, quick on thinking, and acting to save the family. The character of a grasshopper or walang-walangan is keenness, nimbleness, and quickness in moving from one place to another.

In marriage, both the couple should be enthusiastic, keen and nimble to any situation and only by this the family will be saved. Walang-walangan simply means thinking and acting quickly. All the problems should be settled quickly.

If the couple is able to think and act quickly, then the family will be strong family they could survive until the end of their life.

sri penganten kaleh meniko saiki sampon berumah tangga sageto pados

sandang pangan lincah kados walangan. (Koentjaraningrat: 1984: 88)

There is a symbol of smartness and ease represented by a grasshopper. So the couple are expected to have a bright future by working hard and showing responsibility in running their household. Each of them should support their togetherness and only by this way a married life could go towards success. Success does not merely depend on financial standing but also spiritual satisfaction. Above all the couple are expected to have persistence in any step taken. They should not be overcome by obstacles as obstacles are the sign of living. When a man fears to face obstacle, this means that he fears to face life.

\subsection{Pecut-Pecutan as symbol of Optimism}

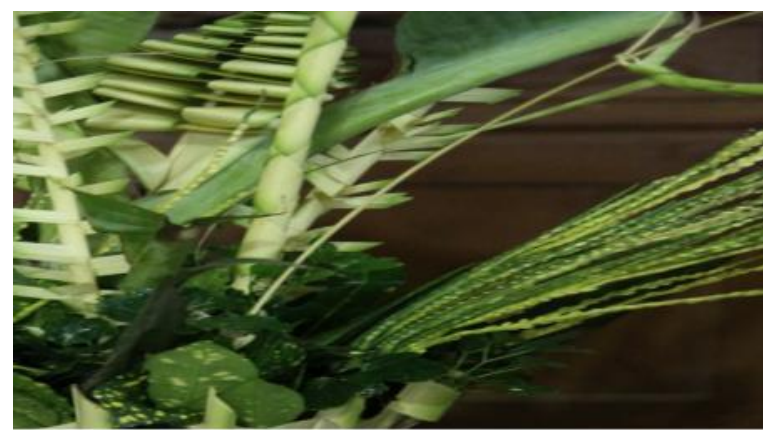

Figure 6. Pecut-pecutan 
Optimism is like a chain that cannot be separated. Human beings living in this world have a hope, and without a hope a man has no a meaning as a human being. Hope is often equated with ambition. Although both seem to have similarity, they are different in the application. A hope is a desire that is not materialized, while ambition is a desire in one's heart. Ambition can be achieved, so ambition can be granted by God. (Walgito, 1997: 94).

This the fourth symbol in the Kembar Mayang named Pecut-pecutan. Symbol of whip In Kembar Mayang means optimism. Pecut pecutan is interpreted as a symbol to be optimistic.

Pecut-pecutan used as a symbol of optimism shows that a marriage will be not eternal and complete without optimistic attitude possessed by both husband and wife. Because the meaning of a whip in its function is "whipping". Whipping here is an attitude to have spirit in working and not to be easily influenced by obstacles.

Pecut; namung setunggal dados sri penganten anyar kaleh meniko sakniki kaleh ngge meniko sampun dados setunggal berumah tangga sageto biso menunggalipun rumah tanggae pun sri penganten anyar kaleh meniko (Hamidin, 2012: 88)

The word pecut is whip and this whip consists of two ropes or threads twisted together to form a strength in striking something. The newly-married couple consists of a man and a woman twisted together in the bond of marriage and they have to work together to form a strength to face all the storms of life. In other words, they have to be optimistic in doing things.

Optimism is an attitude that will encourage the couple to keep trying and never give up in order to reach the ambition and goals, regardless of how serious are the problems faced by the couple. So optimism must be balanced with great effort and faith in God.

\subsection{Keris-kerisan as symbol of Wisdom}

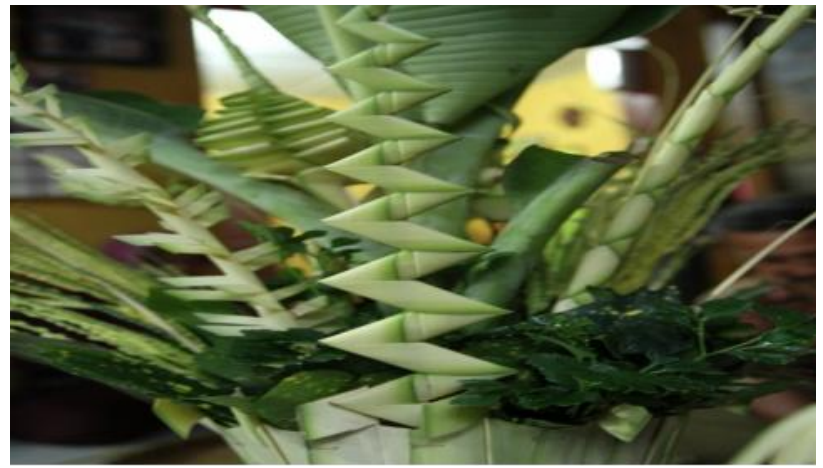

Figure 7. keris-kerisan

Wisdom is the character and the ability to use knowledge, understanding, experience, common sense and deep insight. Wisdom is an accumulation from the science, knowledge and enlightenment. The wise man has the quality of knowledge, and also having the capacity to use it. Someone who knows good input and can process it into a good result is wise. He has a sharpness of intellect, fair, intelligent and proficient about a particular science. (Rice, 1998: 152)

This is the fifth symbol in Kembar Mayang, Kerisan-kerisan. Symbol of Keriskerisan at Kembar Mayang means wisdom. Wisdom is an accumulation of science, 
knowledge and enlightenment. The wise man has the quality of knowledge, and has the capacity to use it.

Keris meniko tajem adem dados sri penganten anyar kaleh meniko sakniki sampon berumah tangga sageto biso tajem pikirane adem lan tentram rumah tangga ne sri penganten anyar kaleh meniko (Hamidin, 2012: 89)

This explains that Keris-kerisan means wisdom. Keris is a traditional Javanese short knife and is used for self-protection and this is the physical meaning of Keris but philosophically a knife can only be used if it is sharp and a man can only be relied upon if the man has a sharp mind meaning that the man can use his mind to solve a problem. Man is man only if he could become a problem solver instead of a problem maker.

Wisdom is an action corresponds with mind, and common sense to get a good, appropriate and right attitude. The meaning of Keris-kerisana in Javanese culture is flexibility in understanding something this also depends on the horizon of thinking and the person's life experience. So, it depends on "Kadhewasa ning Jiwa Jawi", someone's adulthood in thinking and acting wisely.

The richer someone in spiritual experience and knowledge, the stronger he is in problem solving. Here the symbol means that every person must have a patient and wise attitude in facing any situation in life.

\section{Conclusion}

Marriage is very important and it is a sacred social institution. One of the most important parts of a Javanese traditional wedding is Panggih. Panggih ceremony is a meeting ceremony between a groom and a bride after doing Ijab and Kabul and the ceremony is held in the bride's family. In Panggih ceremony there is Kembar Mayang. Kembar Mayang is made from as flowers arranged using janur (young coconut leaves) and some other leaves, and the function is to give guidance and advice to the bride and the groom to undergo a new life.

Kembar Mayang derives from the words Kembar and Mayang. Kembar means equal (podho) and Mayang is heart (ati). So Kembar Mayang means to unite two different hearts to have the same goal.

Kembar Mayang is a kind of bouquet made of different kind of leaves mainly coconut leaves and others stuck into a banana trunk. It is indeed a very beautiful decoration with a broad symbolic meaning. Kembar Mayang is often called Sekar Kalpataru Dewandaru, a symbol of happiness and salvation. This thing is common to decorate the throne or sasana wiwaha that will be occupied by the bride and the groom. Kembar Mayang is used in panebusing sekar mayang step and ritual panggih. When the wedding ceremony is finished, Kembar Mayang twin will be removed at the crossroad of the road, river, or ocean so that the couple always remember their origins.

The research result shows that Kembar Mayang has got some symbolic meanings: loyalty, struggle, persistence, optimism and wisdom, all of which become the base of a harmonious marriage.

Most of the people in Medan Sinembah are Javanese. As the time goes by, Kembar Mayang is always neglected in a marriage ceremony. Even some do not understand all the symbolic meanings found in Kembar Mayang. They simply perform the ceremony without sensing the real meanings of Kembar Mayang.

Through this study it is expected that the revitalization of Kembar Mayang could be done and by this the tradition of making Kembar Mayang in Javanese tradition 
marriage could be preserved. Kembar Mayang is also a self-identity of Javanese people so if this is lost then the self-identity will also be lost.

\section{References}

Cobley, Paul. (2000). The Routledge Companion to Semiotics and Linguistics. London: Routledge.

Hamidin, Aep S. (2012). Buku Pintar Adat Perkawinan Nusantara. Jogjakarta: Diva Press.

Hancock, Mark. (1998). Research Methodology. California: University Press.

Hidayati. (2018). Local Wisdom of Kembar Mayang in Wedding Tradition of Jawa Ethnic Language Literacy, Volume 2, Number 1, June 2018 e-ISSN: 2580-9962 | p-ISSN: 2580-8672 DOI: 10.30743/ll.v2i1.552

John, Paul. (2010). Struggle of Life. New York: Macmillan

Koentjaraningrat. (1984). Kebudayaan Jawa. Jakarta: Balai Pustaka.

Lawrence, William. J. (2009). Personality Adaptation. New York: Hallmark.

Peirce, Charles Sanders. (1990). Collected Papers of Charles Sanders Peirce. Cambridge: Harvard University Press.

Rice, E. F., Jr. (1998). The renaissance idea of wisdom. Cambridge, MA: Harvard University Press.

Ruth, Samantha. (2011). Family Life. Colorado: Baughman Co.

Suwardi. (1993). Bentuk Kembar Mayang Tradisional Jawa Serta Pemahaman Masyarakat terhadap Makna Simboliknya. Malang: Skripsi S1 Jur. Senirupa Malang

Thornbury, Clare. (2011). Pierce's General Theory of Signs. Kyoto University. http://hdl.handle.net/2433/143046

Widagda, Pringga. (2003). Gita Wicara Jawi. Jakarta: Rajawali.

Walgito, Bimo. (1997). Pengantar Psikologi Umum. Cetakan Keempat. Yogyakarta: Andi Offset 